www.jmscr.igmpublication.org

Index Copernicus Value: 79.54

ISSN (e)-2347-176x ISSN (p) 2455-0450

crossref DOI: https://dx.doi.org/10.18535/jmscr/v7i4.110

Journal Of Medical Science And Clinical Research

IGM Publication

An Official Publication of IGM Publication

\title{
Histopathological Study of Non Neoplastic and Neoplastic Lesions of Larynx
}

\author{
Authors \\ Ritu Bhagat ${ }^{1}$, Mandeep Randhawa ${ }^{2}$, Subhash Bhardwaj $^{3}$ \\ ${ }^{1}$ Senior Resident, Deptt. of Pathology, GMC Jammu \\ ${ }^{2}$ Assistant Professor, Deptt. of Pathology, GMC Amritsar \\ ${ }^{3}$ Professor, Deptt. of Pathology, GMC Jammu \\ *Corresponding Author \\ Dr Mandeep Randhawa \\ Email: Mandyrandhawa26@gmail.com,+91-9915785049
}

\begin{abstract}
Background: The larynx serves to protect the lower airways, facilitates respiration and plays a key role in phonation. Lesions of larynx can be classified into commonly occurring non neoplastic and neoplastic lesions.

Materials and Methods: This is a prospective study carried out in department of pathology, GMC Jammu over a period of two years. A total of 90 cases were included in the study.

Results: The peak incidence of benign laryngeal lesions occurred in 30-40 years and malignant lesions in 60-70 years. Both benign and malignant lesions were more common in males as compared to females with M:F ratio of 2:1.Vocal polyp (16.7\%) being the most common tumor like lesion followed by chronic non specific laryngitis(12.2\%).Among the benign tumors squamous papilloma constituted $6.7 \%$ cases and in malignant tumors squamous cell carcinoma constituted $52.2 \%$ cases.

Conclusion: Every tissue removed during laryngeal surgery should be sent for histopathology, as early diagnosis of lesion can lead to effective management.

Keywords: Larynx, tumors of larynx, histopathological.
\end{abstract}

\section{Introduction}

The human larynx protects the lower respiratory tract, provides a controlled airway, allows phonation and the generation of a high intra thoracic pressure for coughing. ${ }^{1}$ The larynx is divided into the supraglottis, glottis and subglottis based on anatomical location. Tumors of the larynx can be divided into benign or malignant. Laryngeal tuberculosis, vocal cord nodules, and vocal cord polyps are tumor like (non neoplastic) lesions of the larynx. Benign laryngeal tumors include a large number of lesions such as papillomas, hemangiomas, fibromas, chondromas, myxomas and neurofibromas. About 95\%of laryngeal carcinomas are typical squamous cell tumors rarely adenocarcinomas are seen to arise from larynx, presumably arising from submucous glands. ${ }^{2}$ The exact cause of laryngeal cancer is still unknown. However, several interrelated cofactors (mainly tobacco smoking and alcohol consumption), are clearly associated with an increased incidence in laryngeal cancer. ${ }^{3}$ 


\section{Materials and Methods}

The present study, which is a prospective, based on study of laryngeal biopsies received in department of pathology, GMC Jammu for a period of two years. A total of 90 cases were included in the study.

\section{Results}

In this study patient's age ranged from 17 years to 81 years .The peak incidence of benign laryngeal lesions was in 30-40 years and malignant lesions in 60-70 years .Both benign and malignant lesions were more common in males as compared to females with M:F ratio of 2:1.

Age wise distribution of cases shown in table 1

\begin{tabular}{|c|c|}
\hline Age in years & Number of cases \\
\hline $10-20$ & 01 \\
\hline $21-30$ & 05 \\
\hline $31-40$ & 20 \\
\hline $41-50$ & 14 \\
\hline $51-60$ & 12 \\
\hline $61-70$ & 31 \\
\hline $71-80$ & 06 \\
\hline $81-90$ & 01 \\
\hline
\end{tabular}

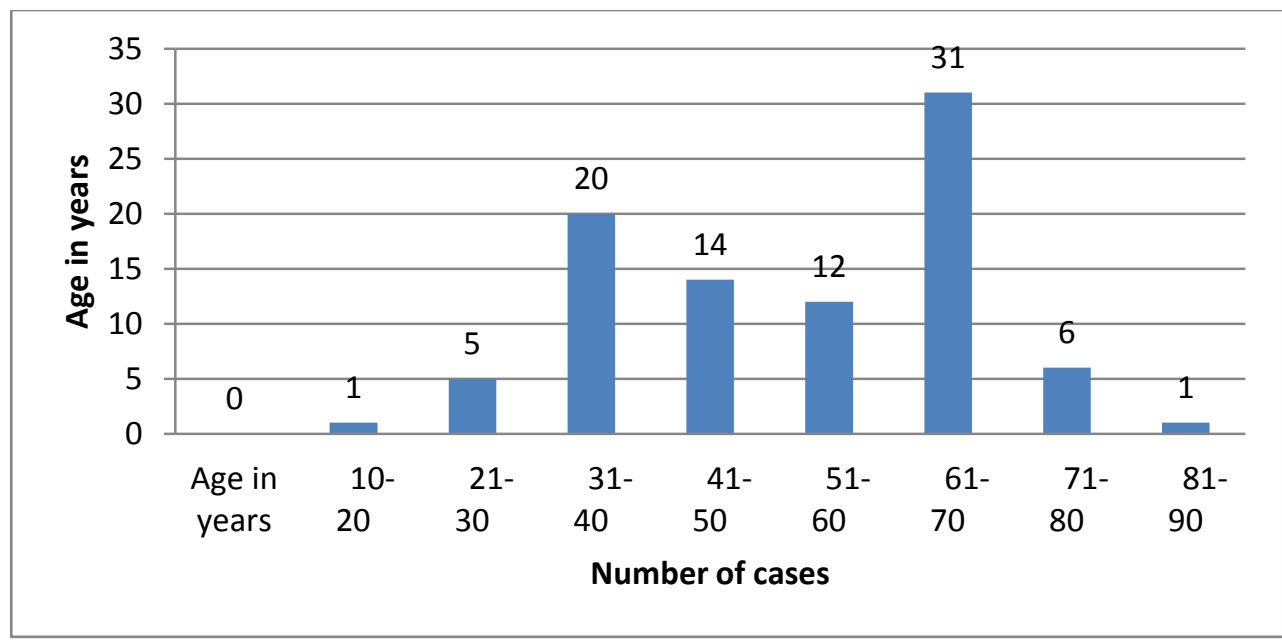

Distribution of various lesions according to histological diagnosis is shown in table 2:

\begin{tabular}{|l|c|c|c|c|c|c|c|c|c|}
\hline $\begin{array}{l}\text { S. } \\
\text { No }\end{array}$ & $\begin{array}{c}\text { Tumor like } \\
\text { lesions }\end{array}$ & No. & \%age & Benign tumors & No. & \%age & Malignant tumors & No. & \%age \\
\hline 1. & Vocal polyp & 15 & $16.7 \%$ & $\begin{array}{c}\text { Squamous } \\
\text { papilloma }\end{array}$ & 06 & $6.7 \%$ & $\begin{array}{c}\text { Squamous cell } \\
\text { carcinoma }\end{array}$ & 47 & $52.2 \%$ \\
\hline 2. & Vocal nodule & 08 & $8.9 \%$ & Hemangioma & 01 & $1.1 \%$ & adenocarcinomas & 01 & $1.1 \%$ \\
\hline 3. & $\begin{array}{c}\text { Tubercular } \\
\text { laryngitis }\end{array}$ & 01 & $1.1 \%$ & & & & & & \\
\hline 4. & $\begin{array}{c}\text { Chronic non } \\
\text { specific } \\
\text { laryngitis }\end{array}$ & 11 & $12.25 \%$ & & & & & & \\
\hline & Total & 35 & $38.9 \%$ & & 07 & $7.8 \%$ & & 48 & $53.3 \%$ \\
\hline
\end{tabular}

Distribution of benign and malignant lesions is shown in table 3:

\begin{tabular}{|l|c|c|c|}
\hline S. No. & Lesion & Number of cases & Percentage \\
\hline 1. & Benign tumors & 07 & $7.8 \%$ \\
\hline 2. & Malignant tumors & 48 & $53.3 \%$ \\
\hline
\end{tabular}




\section{JMSCR Vol||07||Issue ||04||Page 640-644||April}

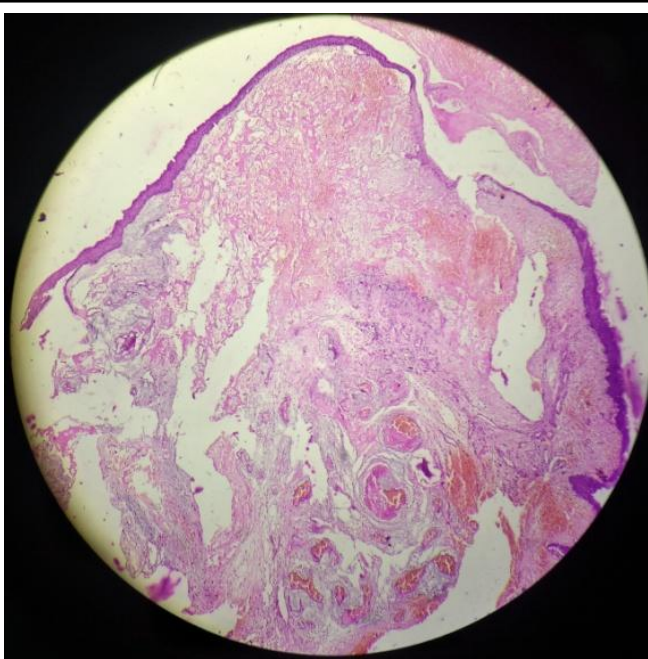

Figure 1: Vocal Nodule

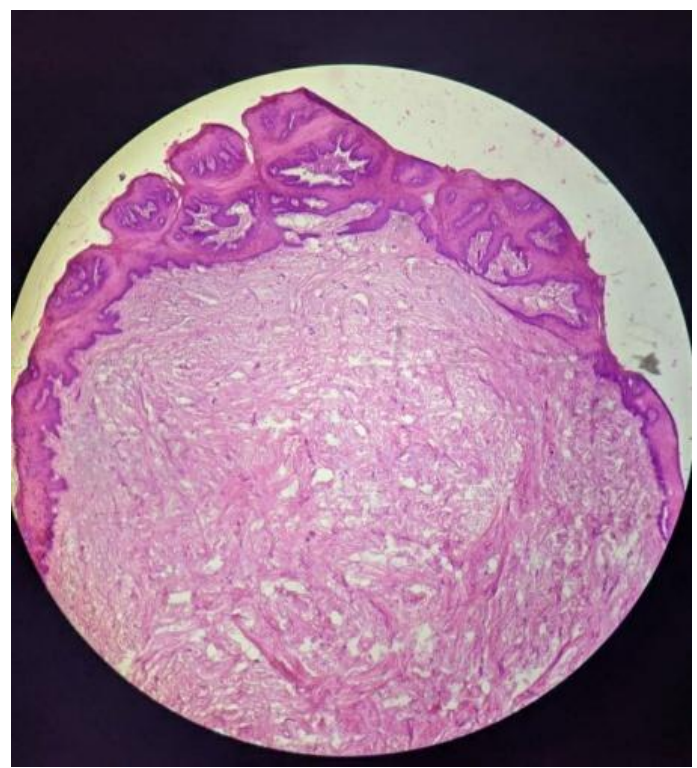

Figure 2: Squamous Papilloma

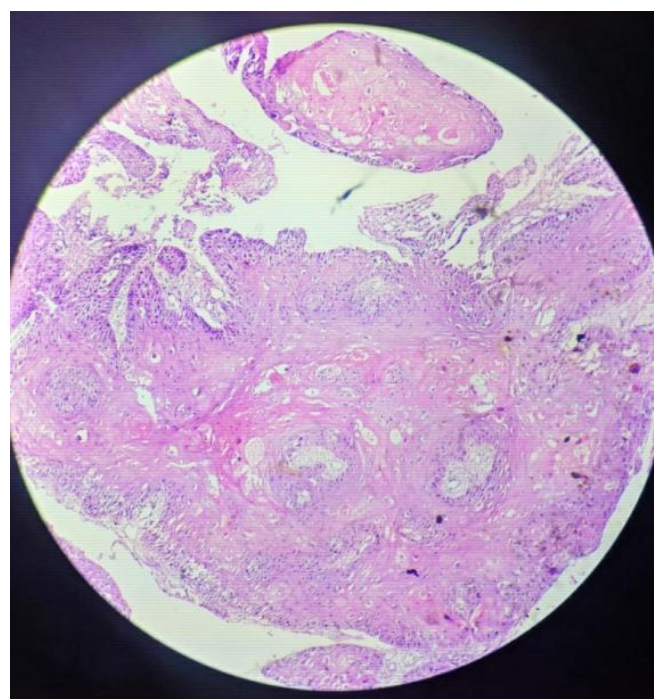

Figure 3: Squamous Cell Carcinoma

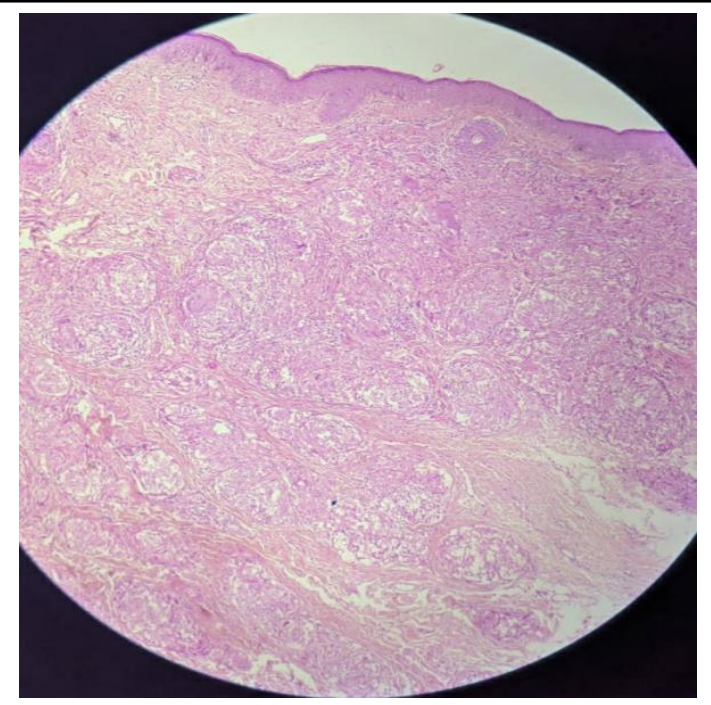

Figure 4: Laryngeal Tuberculosis

\section{Discussion}

Tumors of the larynx are usually detected early due to dysphonia i.e change in voice. Benign tumors were most common in the third decade, smilar results reported by Hegde MC et $a l^{4}$ and Singhal $\mathrm{P}$ et $a .^{5}$ Malignant tumors were seen in between the age group of $41-70$ years with maximum occurrence between the age of 61-70 years. Shirley D et $a l^{6}$ stated that malignant tumors tend to increase with age, average age of diagnosis been 66 years.

In our study both malignant and benign malignant lesions were common in males as compared to female with $\mathrm{M}: \mathrm{F}$ ratio of $2: 1$, these results were comparable with study by Wani et $a l^{7}$. The male preponderance could be attributed to vocal abuse, occupation, smoking and drinking alcohol habits in males.

Non neoplastic lesions constituted about 39\% of cases with vocal polyp being the commonest type. A vocal polyp is covered with stratified squamous epithelium and may exhibit a variety of changes in the stroma which include oedema, fibrosis, increased vascularity, haemorrhages and hyaline changes. In our study there were $16.7 \%$ cases of vocal polyp as compared to $16 \%$ in Chopra et al . and $31.4 \%$ in Kavitha $\mathrm{Y}$ et al .

Second most common non neoplastic lesion noticed was chronic non specific laryngitis with 11 cases $(12.2 \%)$. Varalakshmi KP et al ${ }^{10}$ reported $24.2 \%$ and $26 \%$ by Chavan SS et al. ${ }^{11}$ 
Our study reported 8 cases $(8.9 \%)$ of vocal nodule, similar finding was observed by Varalakshmi KP et $a l^{10}$ with $8.4 \%$ cases.

01 case $(1.1 \%)$ of tuberculosis of larynx was observed in our study,this finding is in accordance with Varalakshmi KP et $a l^{10} .(1.1 \%)$, Chaitanya V et $a l^{12}(2.5 \%)$ and $3 \%$ by Kavitha Y et al ${ }^{9}$.

Neoplastic lesion constituted $61.1 \%$ of cases with $7.8 \%$ benign tumors and $53.3 \%$ malignant tumors. Among the benign neoplastic lesions, squamous papilloma was the predomimnant type. It is benign epithelial neoplasm formed by stratified squamous epithelium. These tumors are usually exophytic.6.7\% cases were seen in our study, this is correlated with Chavan SS et $a l^{11} 6 \%$, Kavitha Y et $a l^{9} 8 \%$ and $10 \%$ by Chaitanaya $\mathrm{V}$ et $a l^{12}$.

01 case $(1.1 \%)$ of hemangioma was observed in our study, similar result observed by Varalakshmi $\mathrm{KP}$ et $a l^{10}$ with $1.1 \%$ case.

Squamous cell carcinoma (47 cases) was the commonest malignant neoplasm comprising of $52.2 \%$ with majority of them being well differnentiated followed by moderately diffentiated squamous cell carcinoma. Varalakshmi KP et al ${ }^{10}$ reported $41.1 \%$ cases and $36.4 \%$ cases by Kavitha $\mathrm{Y}$ et al ${ }^{9}$. Squamous cell carcinoma often arises in a background of mucosal squamous dysplasia or carcinoma in situ and typically presents islands, tongues, and clusters of atypical cells invading the laryngeal stroma.

01 case $(1.1 \%)$ of adenocarcinoma of larynx was reported in our study this is in accordance with Varalakshmi KP et al ${ }^{10}(1.1 \%)$.

\section{Conclusion}

The symptoms of laryngeal tumors can vary from mild hoarseness of voice to life threatening repiratory distresss. All available methods should be utilised to make the diagnosis as early as possible. Laryngeal lesions can create lot of mental and emotional stress in the patient and family. Early diagnosis of the lesion can lead to effective management.

\section{References}

1. Beasley N. Anatomy of the larynx and tracheobronchial tree.In: scott- Brown's otolaryngology, head and neck surgery, $7^{\text {th }}$ edn edited by Micheal Gleeson. Great Britain: Hodder Arnold; 2008:2130-2144.

2. Sharma DK, Sohal BS, Bal MS, Aggarwal S.Clincopathological study of 50 cases of tumors of larynx.Indian J Otolaryngol Head Neck Surg.2013;65 (suppl 1):29-35.

3. Robin PE, Olofsson J (1997)Tumors of the larynx. In: Hibbert J(ed) Laryngology and head and neck surgery, $6^{\text {th }}$ edn. Heinemann International, Great Briatain, pp 1-9.

4. Hegde MC, Kamath MP, Bhojwani K, Peter R, Babu PR et al. Benign lesions of larynx-a clinical study. Ind J Otolaryngol and Head Neck Surg 2005;57(1):35-38.

5. Singhal P, Bhandari A, Chouhan M, Sharma MP, Sharma $S$ et al . Benign tumors of larynx: A clinical study of 50 cases. Ind J Otolaryngol Head Neck Surg 2009,(suppl1);26-30.

6. Shirley D (1997) Cartilaginous lesions of the larynx. Grand rounds archives BCM. Bobby R Alford Department of otolaryngology: Head and neck surgery.

7. Wani AA, Rehman A, Hamid S, Akhter $\mathrm{M}$, Baseena S. Benign mucosal fold lesion as a cause of hoarseness of voice. A Clinical study. Otolaryngology. 2012;2(3):120.

8. Chopra H, Kapoor M. Study of benign glottis lesions undergoing microlaryngeal surgery.Indian J Otolaryngol Head Neck Surg.1997;49:276-9.

9. Kavitha Y, Chaitanya V, Basavaraju KP. Tumors and tumor like lesions of larynx : a clinicopathological study .Int J Otolarhinolaryngol Head Neck Surg 2018; 4:794-9.

10. Varalakshmi KP, Naik VS, Swapna RS, Sravani P, Padmaja MN. Laryngeal Biopsies with special references to 
malignanat tumors: A Histological study .Int J sci stud 2016;4(3):197-202.

11. Chavan SS, Yewale AG. Clinicopathological profile of patients with benign laryngeal lesions.MedPulse International Journal of ENT. September 2017;3(3):26-28.

12. Chaitnaya V, Nikethan B. Clinicopathological study of non neoplastic and neoplastic lesions of larynx. Int J Intg Med Sci 2015;2(12):200-205. 